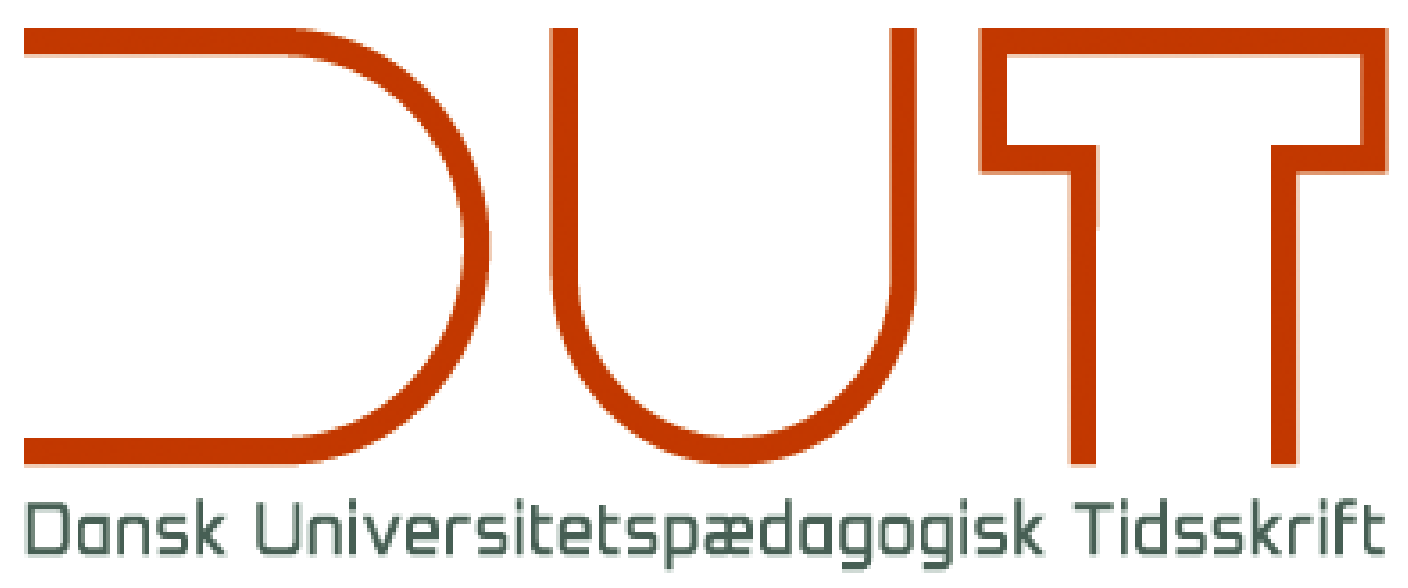

Læringsrum

Årgang 14 nr. 27 / 2019

Titel

DUT Guiden rækker hånden ud til underviserne

Forfattere

Kim J. Herrmann

Sidetal

$1-2$

Udgivet af

Dansk Universitetspædagogisk Netværk, DUN

URL

> http://dun-net.dk/

Betingelser for brug af denne artikel

(c) Copyright
Denne artikel er omfattet af ophavsretsloven, og der må citeres fra den. Følgende betingelser skal dog være opfyldt:

- Citatet skal være i overensstemmelse med "god skik"

- Der må kun citeres „i det omfang, som betinges af formålet“

- Ophavsmanden til teksten skal krediteres, og kilden skal angives ift. ovenstående bibliografiske oplysninger.

DUT og artiklens forfatter 


\title{
DUT Guiden rækker hånden ud til underviserne
}

\author{
Kim J. Herrmanna, 1 \\ aAnsvarshavende redaktør for DUT
}

\section{En ny artikeltype er født}

Dansk Universitetspædagogisk Tidsskrift (DUT) har indført en ny artikelgenre - DUT Guiden med det formål at formidle praksisnære råd til undervisere på danske universiteter. De første DUT Guides om det internationale klasserum (Lauridsen 2019) og akademisk skrivning (Wirenfeldt Jensen 2019) udkom i foråret. Denne udgave af tidsskriftet indeholder råd til at vælge indhold (Keiding 2019) samt råd om implementering af peer-feedback (von Müllen 2019). Forhåbentlig er dette de første fire i en lang serie af praksisnære og handlingsrettede artikler.

\section{Målgruppen}

DUTs eksistensberettigelse er at bidrage til at beskrive, understøtte og udvikle universitetspædagogiske praksisser.

Tidsskriftet henvender sig derfor til undervisere, som gerne vil udvikle deres undervisningseller vejledningspraksisser, udviklere, som gerne vil kvalificere deres udviklingsarbejde, forskere, som gerne vil udvikle det universitetspædagogiske forskningsfelt og bes/utningstagere, som gerne vil informere deres beslutninger.

Redaktionen har gennem årene erfaret, at tidsskriftet har en stor og bred læserskare, særligt blandt undervisningsudviklere, universitetspædagogiske forskere og uddannelsesansvarlige. Formålet med at indføre DUT Guides er at appellere mere direkte til gruppen af undervisere og andre udøvere, som søger tekster, der kan omsættes til handling. Det stiller særlige krav til format og indhold.

\section{Mellem tung teori og letbenede tips og tricks}

Hvis du har prøvet at afholde et universitetspædagogisk kursus, så har du sandsynligvis gjort dig følgende erfaring: At det er særdeles vanskeligt at finde tekster, som passer til målgruppen.

Måske er teksten for lang. Eller måske for kort? Måske er teksten tung på teori og empiri, men tynd på konkrete råd. Måske rummer teksten 101 praktiske råd, men er blottet for beskrivelser af den underliggende teoretiske eller empiriske præmis. Måske er teksten faktisk rigtig god, men den er skrevet til folkeskolen, og derfor risikerer den at blive afvist af den universitetsansatte læser.

DUT Guiden tager udgangspunkt i otte til 10 konkrete og praksisnære råd. Den beskriver i korthed det forskningsmæssige grundlag for rådene. Den begrænser sig til 3.000 ord.

Vi i redaktionen håber derfor at imødekomme et behov, som tidsskriftets faglige og videnskabelige artikler ikke nødvendigvis dækker. Vi håber ligeledes, at DUT Guides ikke bliver en

${ }^{1}$ Kontakt: kh@au.dk 
erstatning for længere artikler eller lærebøger, men at guiderne giver læseren lyst til at fordybe sig i feltets øvrige litteratur.

\section{En åben invitation}

DUT Guiden er til for at blive anvendt.

Vi håber, at du som underviser har lyst til at læse guiderne og anvende rådene i din undervisning. Vi håber, at du som universitetspædagogisk udvikler har lyst til at anvende guiderne på kurser og i workshops. Vi håber, at du som universitetspædagogisk forsker har lyst til at omsætte din forskning til konkrete råd baseret på den nyeste forskning. Og endelig håber vi, at du som bes/utningstager vil udbrede kendskabet til guiderne på din institution.

Alle med den fornødne ekspertise kan bidrage til fremtidens DUT Guides efter aftale med redaktionen. Og alle med interesse for universitetspædagogik er velkommen til at foreslå temaer og komme med feedback til redaktionen.

God læselyst.

\section{Referencer}

Keiding, T. B. (2019) DUT Guide: Undervisningens indholdsvalg. Dansk Universitetspoedagogisk Tidsskrift, 14(27).

Lauridsen, K. M. (2019) DUT Guide on teaching and learning in the international classroom. Dansk Universitetspoedagogisk Tidsskrift, 14(26), 125-132.

von Müllen, R. L. (2019) DUT Guide til Peer-Feedback Dansk Universitetspœedagogisk Tidsskrift, 14(27).

Wirenfeldt Jensen (2019) DUT Guide om akademisk skrivning. Dansk Universitetspoedagogisk Tidsskrift, 14(26), 115-124. 